\title{
A modified high-fat diet and its effect on histopathological features of mice liver as an alternative diet for animal model of liver cell damage
}

\author{
Dzul Fithria Mumtazah ${ }^{1 *}$, Hendri Busman ${ }^{1}$, Mohammad Kanedi $^{1}$, Gina Dania Pratami ${ }^{1}$ \\ ${ }^{1}$ Department of Biology, Faculty of Mathematics and Natural Sciences, Universitas Lampung \\ Jl. Prof. Soemantri Brodjonegoro No. 1 Rajabasa Bandar Lampung, Lampung, Indonesia, 35141 \\ *Email: dzul.mumtazah@fmipa.unila.ac.id
}

\begin{abstract}
Researchers attempted to obtain animal models that experienced hypercholesterolemia and led to liver damage to determine the performance of the liver. Rats were chosen because of the ease of handling, collecting organ and blood samples. Still, their high price and availability that are more difficult to find have made some researchers look for alternatives to other animal models such as mice. This study aims to determine the role of a modified high-fat diet as an alternative diet for mice to experience hepar damage. Male mice treated for four and eight weeks with a modified high-fat diet were sacrificed for their liver, then they were tested for histopathology using the paraffin method and HE staining. The characterization of hepar damage traits was carried out to score the degree of parenchymal degeneration, hydropic degeneration, and necrosis. The results showed that the control group, four and eight weeks of atherogenic diet had more than $50 \%$ cell damage, presumably due to the role of the starch mixture in feed as a source of carbohydrates through the mechanism of converting carbohydrate pathways into fat which damages liver cells.
\end{abstract}

Keywords: atherogenic diet; hepar damage; liver histopathological features; Mus musculus L.; starch mixture

\begin{abstract}
Article History: Received 10 September 2021; Received in revised form 21 October 2021; Accepted 14 November 2021; Available online 30 December 2021

How to Cite This Article: Mumtazah DF, Busman H, Kanedi M, Pratami GD. 2021. A modified high-fat diet and its effect on histopathological features of mice liver as an alternative diet for animal model of liver cell damage. Biogenesis: Jurnal Ilmiah Biologi. vol 9(2): 171-177. doi: https://doi.org/10.24252/bio.v9i2.24081
\end{abstract}

\section{INTRODUCTION}

Due to plaque buildup, hardening the artery walls is a common disease with more than two million cases per year in Indonesia with prevalence reaching 1.5-2\% and exacerbated by COVID-19 infection (Kementerian Kesehatan, 2021). It is the forerunner of coronary heart disease with high mortality and morbidity rates. The risk factors that support the number of sufferers of this disease are smoking habits, hypertension, diabetes, and an unbalanced diet rich in fat that causes blood lipid levels to become abnormal (Bhupathiraju \& Tucker, 2011; Santoso et al., 2020). Abnormal levels of lipids in the blood due to an increase in the amount of cholesterol, modified lipids, and lousy fatty acids, which then increase inflammatory reactions in blood vessels, are one of the factors that increase atherosclerotic progression that causes plaque to appear (Murakami et al., 2016; Poston, 2019). The process of changing the lipid substance and the inflammatory reaction is facilitated by the secretory phospholipase A2 (sPLA2) enzyme group (Murase et al., 2016), which plays a role in forming atherosclerotic plaque in blood vessels and its prevention (Lind et al., 2012; Rosenson \& Hurt-Camejo, 2012). Accumulation of fat levels can also occur in the liver, which causes fatty liver. Fatty liver disease is a term used to indicate a condition when there is an excessive accumulation of fat in the liver (Maurice \& Manousou, 2018). This condition makes it difficult for the liver to work.

Research on fatty liver and hypercholesterolemia uses many experimental animals, like mice, rats, and other primates. The degree of steatosis, lobular inflammation, and ballooning hepatocytes on the results of liver histopathology tests can be utilized to diagnose (Adiwinata et al., 2015), which are further classified as parenchymatous degeneration, hydropic degeneration, and necrosis. Hydropic degeneration is also known as ballooning, toxic cell swelling, vacuolar degeneration, or hydropic changes. Although this sort of liver cell damage is not lethal, it can serve as a precursor to necrosis and cell lysis if it persists. Hydropic degeneration is indicated by cells 
with wide cavities, separate organelles, and irregularly stacked (Abdelzaher et al., 2018; Asuzu et al., 2019). Parenchymatous degeneration is also characterized by vacuolar swelling (Stanek et al., 2015). Liver cell necrosis shows swollen cells that secrete evisceration, eosinophilia, karyolysis, and induce inflammation (Al-Griw et al., 2016).

One of the methods for inducing liver damage in mice or other experimental animals is to feed them a high-fat diet. A previous study on modified high-fat diet in mice was carried out by Lee et al. (2011), the chemicallymodified resistant starch type-4 and highamylose corn starch was capable to reduce the level of total lipid and total cholesterol. Followed by Zheng et al. (2020) which used rice starch oleic acid complex as a supplementary diet for rats fed with high-fat diet that was able to lose their weight and correlated with HDL-c and SOD levels. This study aims to determine the role of a modified high-fat diet as an alternative diet for mice to experience hepar damage. In this case, the authors developed a modified high-fat diet capable of inducing liver damage in mice as a substitute for rats, which are more expensive and difficult to obtain as laboratory animals. This modified high-fat diet could be duplicated as a new alternative composition diet to induce liver damage in mice.

\section{MATERIALS AND METHODS}

This research was conducted in JulyNovember 2020. The maintenance of experimental animals was carried out at the Laboratory of Zoology, Faculty of Mathematics and Natural Sciences, Universitas Lampung, and histopathological tests of liver organs were carried out at the Veterinary Center of Lampung Province.

Animals and experimental design. A total of 15 healthy male mice (Mus musculus L.) aged two-three months weighing 35-40 grams were used as animal models; for four and eight weeks, they were given animal feed consisting of PAR-S feed (JAPFA® Comfeed), quail egg yolk cholesterol, wheat flour, and pork oil. Experimental animals were grouped into three treatment groups: control mice, mice with an atherogenic diet for four weeks, and mice with an atherogenic diet for eight weeks. The composition of the high-fat and atherogenic diet is shown in Table 1. The experimental group feed was added with pork oil and quail egg yolk as a source of cholesterol which is expected to provide a more atherogenic condition in the feed (Murwani et al., 2013).

Table 1. Modified high-fat and atherogenic diet composition.

\begin{tabular}{llll}
\hline Composition & $\begin{array}{l}\text { Grup } \\
\text { Control }\end{array}$ & 4 weeks & 8 weeks \\
\hline $\begin{array}{l}\text { Comfeed } \\
\text { broiler }\end{array}$ & $53 \%$ & $50 \%$ & $50 \%$ \\
$\begin{array}{l}\text { Wheat flour } \\
\text { (starch) }\end{array}$ & $24 \%$ & $25 \%$ & $25 \%$ \\
Lard oil & $0 \%$ & $10 \%$ & $10 \%$ \\
$\begin{array}{l}\text { Yolk quail } \\
\text { Water }\end{array}$ & $0 \%$ & $5 \%$ & $5 \%$ \\
\hline
\end{tabular}

Histopathological preparation. After the specified time (four and eight weeks), the liver was taken from the mice for making histopathological preparations at the next stage. The liver tissue obtained was soaked in a fixative solution for $24 \mathrm{~h}$, then the organs were cut with a size of $5 \times 5 \mathrm{~cm}$ and soaked in $70 \%$ alcohol for $24 \mathrm{~h}$. The next step is dehydration, the tissue is immersed in $70 \%, 80 \%, 90 \%, 96 \%$, and $100 \%$ alcohol for $30 \mathrm{~min}$. Next is the immersion of the tissue in a combination of alcohol:xylene $(3: 1,1: 1,1: 3$, and $0: 1)$ for 15 min each. Then the paraffin blocks were molded and cut using a microtome with a thickness of $3 \mu \mathrm{m}$. The tissue slices were then attached to an object glass, and then the tissue was immersed in xylene I and II for $15 \mathrm{~min}$ each. After that, it was soaked again in $100 \%$, $96 \%, 90 \%, 80 \%$, and $70 \%$ alcohol for $5 \mathrm{~min}$, then soaked in clean water for $1 \mathrm{~min}$, hematoxylin for $15 \mathrm{~min}$, rinsed with running water for $1 \mathrm{~min}$, soaked in eosin for 5-10 s, immersed in $70 \%$ alcohol I enough to rinse off the color, then alternately immersed in $70 \%$ alcohol II, 80\%, 90\%, 96\%, 100\% I and $100 \%$ II for 1-5 min respectively and soaked in xylene:alcohol (1:1) for $15 \mathrm{~min}$, soaking the tissue in xylene I for $15 \mathrm{~min}$, soaking the tissue in xylene II for at least $15 \mathrm{~min}$, then closing the tissue with enough entellan ${ }^{\circledR}$ glue (Merck) 
(adhesive) on the object glass, and closed with a cover glass, the preparations were then observed under a microscope (Raharjo et al., 2013). The description of the histopathological test of each mouse liver was then observed in five fields of view, with magnifications of $100 \times$ and $400 \times$, and the degree of liver damage was scored according to the category with modified scoring guidelines from Manja-Roenigk (Raharjo et al., 2013) as shown in Table 2.

Table 2. Guidelines for scoring the degree of liver damage in mice on a high-fat and atherogenic diet.

\begin{tabular}{ll}
\hline Degree of liver damage & Score \\
\hline Normal & 1 \\
Parenchymatous degeneration & 2 \\
Hydropic degeneration & 3 \\
Necrosis & 4 \\
\hline
\end{tabular}

Data analysis. The results of scoring the degree of liver damage were then tabulated and statistically tested to define differences in the effects of a high-fat and atherogenic diet between groups using a t-test.

\section{RESULTS AND DISCUSSION}

Research about high-fat levels is still a fresh and promising topic for preventing metabolic syndrome. Several researchers attempted to obtain animal models that experienced hypercholesterolemia and lead to hepar damage to determine the function of a substance or organic property on the performance of fatty organs, one of which is the liver. The liver plays a role in many processes in the body, and its damage can have disastrous consequences in metabolism, immune response, detoxification, and defense against microbes (Zhou et al., 2016). Hepatocytes are the primary cells responsible for the central role of the liver in metabolism. Apart from protecting the body against the accumulation of harmful substances from the outside and within, the liver also serves as a location for the metabolization of drugs and other toxic substances (Freitas et al., 2017; Li et al., 2019; Schulze et al., 2019).

The addition of lard and quail egg yolk to the modified atherogenic diet had no significant effect on the bodyweight of mice between control and four weeks groups and the extent of liver cell damage. It is demonstrated that all groups have a high body mass index (Fig. 1) and a high rate of liver damage (Table 3 ). The fluctuation of body weight from week to week is presumably due to the eating habit of the animals and the duration of the maintenance, resulting in an increase and decrease in body weight because of dietary factors (Gargiulo et al., 2014).

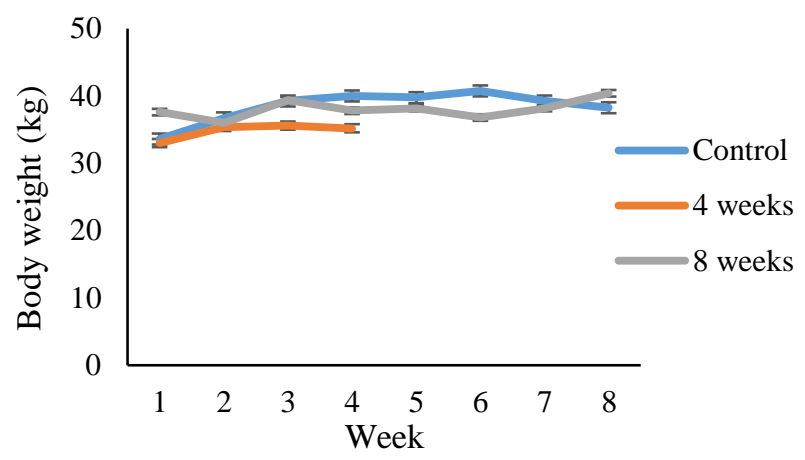

Fig. 1. Bodyweight of animal model with modified atherogenic diet (the t-test revealed a significant difference in body weight between the control group and the 4-week atherogenic group (p-value 0.000), but no significant difference between the control group and the 8-week atherogenic group (p-value 0.097)).

The independent t-test showed that the total number of damaged cells (experiencing parenchymatous degeneration, hydropic degeneration, and necrotic) in the atherogenic diet group was significantly different from the control group, with the damage for all groups more than $50 \%$, although the difference in the number of damaged cells between groups was slight (Table 3).

Table 3. Liver cell damage in the control group, four weeks atherogenic group, and eight weeks atherogenic group.

\begin{tabular}{llll}
\hline \multirow{2}{*}{ Criteria } & \multicolumn{3}{l}{ Mean \pm SD } \\
& Control & 4 weeks & 8 weeks \\
\hline \multirow{2}{*}{ Total cells } & $198.8 \pm$ & $234.64 \pm$ & $314.44 \pm$ \\
& 26.66 & 53.80 & 21.30 \\
Normal cells & $18.4 \pm$ & $24.2 \pm$ & $34.88 \pm$ \\
Parenchymatous & 25.28 & 15.39 & 24.25 \\
degeneration & $22.71 \pm$ & $95.6 \pm$ & $78.48 \pm$ \\
Hydrophic & $20.05 \pm$ & 22.04 & 22.37 \\
degeneration & 9.00 & $23.77 \pm$ & $90.76 \pm$ \\
Necrotic & $82.2 \pm$ & $84.52 \pm$ & 45.57 \\
Total damage & 12.83 & 52.75 & 31.25 \\
cells & $180.4 \pm$ & $210.44 \pm$ & $279.56 \pm$ \\
Notes: ab $=$ p-value $\leq 0.05$. & $36.34^{\mathrm{a}}$ & $59.54^{\mathrm{b}}$ & $12.11^{\mathrm{b}}$ \\
\hline
\end{tabular}


Histopathological appearance of liver cells in Fig. 2 revealed normal cells and cells with varying degrees of damage, including parenchymatous degeneration, hydropic degeneration, and necrosis. Hydropic degeneration is characterized by swollen cells, irregular shapes, and separated organelles.

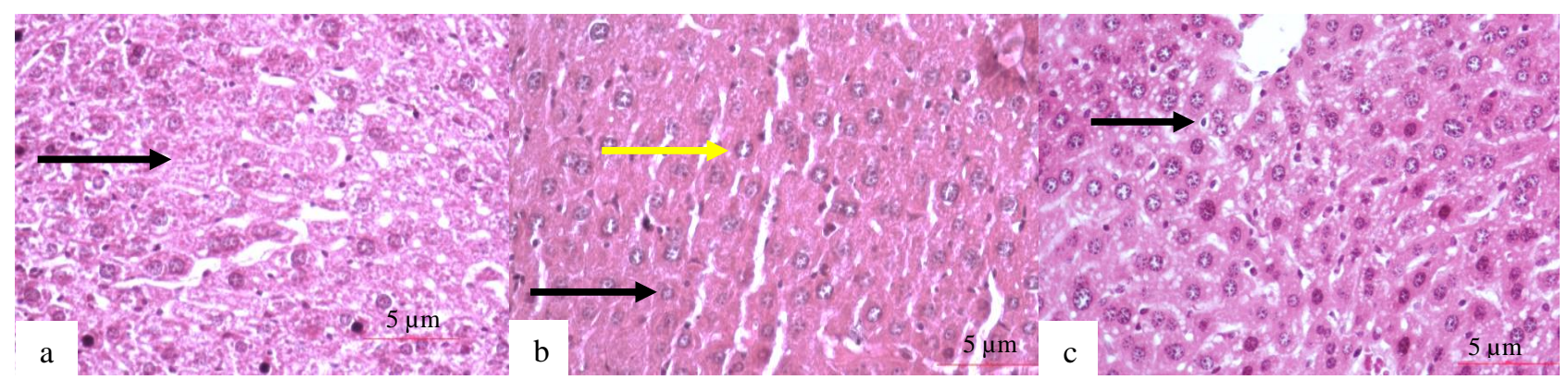

Fig. 2. Histopathological features of the liver cells of mice: a. control group (black arrow= normal cells); b. Four weeks atherogenic diet (yellow arrow= hydropic degeneration; black arrow= parenchymatous degeneration); c. Eight weeks atherogenic diet (black arrow= necrosis).

In our study, the results of the independent t-test showed that the total number of damaged cells (experiencing parenchymatous degeneration, hydropic degeneration, and necrotic) in the atherogenic diet group was significantly different from the control group, with the percentage of damage for all groups more than $50 \%$ (Table 3), although the difference in the number of damaged cells between groups was slight. Hepatocytes, as a constituent of the liver, can be damaged due to various things, one of which is the initial fatty process that changes hepatocytes in various degrees of damage, namely parenchymatous degeneration, hydropic degeneration, and necrosis (Jarrar \& Taib, 2012; Ruan et al., 2013; Gissen \& Arias, 2015). Parenchymatous degeneration occurs due to the absorption of toxic substances and lead $\mathrm{s}$ to mitochondrial swelling and the formation of cytoplasmic vacuoles in hepatocytes; this is a part of an adaptive response and usually subside in a short time, parenchymatous degeneration is reversible (Stanek et al., 2015). Meanwhile, hydropic degeneration generally results from ion and fluid homeostasis that increases intracellular water (Abdelhalim \& Jarrar, 2011; Ramos et al., 2015). In addition, when hydropic degeneration occurs, the clear zone in the cytoplasm is a site for glycogen accumulation. Hepatocytes that experienced hydropic degeneration during HE staining looked pale, enlarged in size, and had sparse cytoplasm containing fine granules. The cytoplasm in hepatocytes with severe swelling is lighter in color, called ballooning degeneration (Ruan et al., 2013). Necrosis of hepatocytes causes the cells to lose cell membrane integrity, and intracellular content is typically released, causing inflammation of the surrounding tissues. Increased eosinophils, vacuoles in the cytoplasm following organelle digestion, and nuclear changes such as karyolysis, cariorrexis, and pyknosis all indicate necrotic cells (Panqueva, 2013; Freitas et al., 2017).

Changes in lipid levels in the body resulting from the imbalance between lipolysis, lipid uptake, lipogenesis, and lipid oxidation can cause organelle dysfunction in hepatocytes, such as mitochondrial dysfunction, lysosomal dysfunction, extracellular vesicle secretion, and hypoxia which leads to necrosis and cell death (Geng et al., 2021). Accumulation of fat in the liver that causes hepatocyte damage is a precursor to non-alcoholic fatty liver disease (NAFLD), liver cirrhosis and is an independent predictor of cardiovascular disease (Wang et al., 2013). However, based on the data, hepatocyte damage occurred in all groups (Table 3), which is thought to be caused by the feed's high starch content. It is consistent with a previous study by Basaranoglu et al. (2015) that ingested carbohydrates are a significant of hepatic de novo lipogenesis (DNL) and are more likely than dietary fat to directly contribute to NAFLD (Byrne \& Targher, 2015; Maurice \& Manousou, 2018). Rats are the most frequently used animal models $(95 \%$ of the 
time) in animal models studies (Hickman et al., 2017; Szpirer, 2020) because of their similarity to existing systems in humans and rats. Mice are not included under the Animal Welfare Act Regulations. Besides, rats were chosen because of a known genetic background, short generation time, similarities to human disease conditions, known microbial status, the ease of handling and taking organ and blood samples (Hawkins et al., 2015). However, their high price and availability that are more difficult to find have made some researchers (especially student) have to look for alternatives to other animal models such as mice (Bryda, 2013).

The diet contains a high amount of starch, and commercial feeds result in excess calories and contribute to obesity and insulin resistance. Additionally, obesity may influence fat accumulation in the liver by adiponectin levels (fatty acid oxidation), and insulin resistance contributes to hepar damage by increasing de novo lipogenesis (Zheng et al., 2015; Gao et al., 2020). This resulted in all groups (control and experiment) in Fig. 2, exhibiting symptoms consistent with liver cell damage caused by lipid accumulation and parenchymatous degeneration, hydropic degeneration, and necrosis in all histopathological preparations.

\section{CONCLUSION}

Although the difference was slight, the mean number of damaged cells was significantly different between the control and the four-week and eight-week atherogenic diet groups. All groups demonstrated a level of cell damage more significant than 50\%, presumably due to the starch mixture's role in feed as a source of carbohydrates via the mechanism of carbohydrate pathways converting to fat, which damages liver cells. Alternative feeds containing flour, broiler comfeed, water, quail egg yolk, and pork oil can generate animal models of liver damage.

\section{ACKNOWLEDGEMENTS}

This study was conducted as part of the research project. We thank LPPM Universitas Lampung for the research funding support (No. 1635/UN26.21/PN/2021), Faradhila Amanda, and Ahad Putra Dewantara for assisting in animal handling.

\section{REFERENCES}

Abdelhalim MAK, Jarrar BM. 2011. Gold nanoparticles induced cloudy swelling to hydropic degeneration, cytoplasmic hyaline vacuolation, polymorphism, binucleation, karyopyknosis, karyolysis, karyorrhexis and necrosis in the liver. Lipids in Health and Disease. vol 10(1): 1-6. doi: https://doi.org/10.1186/1476-511X-10-166.

Abdelzaher OF, Abdoon AS, Rady MI, Abd-Elgalil MM, Mehany AB, Mohammed FE. 2018. Hepatic and renal histopathological and ultrastructural alterations following exposure to different gold nanoparticle sizes in female pregnant rats. Al-Azhar Bulletin of Science. vol 29(2): 25-38. doi: https://dx.doi.org/10.21608/absb.2018.33816.

Adiwinata R, Kristanto A, Christianty F, Richard T, Edbert D. 2015. Tatalaksana terkini perlemakan hati non alkoholik. Jurnal Penyakit Dalam Indonesia. vol 2(1): 53-59. doi: http://dx.doi.org/10.7454/jpdi.v2i1.65.

Al-Griw MA, Alghazeer RO, Al-Azreg SA, Bennour EM. 2016. Cellular and molecular etiology of hepatocyte injury in a murine model of environmentally induced liver abnormality. Open Veterinary Journal. vol 6(3): 150-157. doi: https://doi.org/10.4314/ovj.v6i3.1.

Asuzu IM, Ugwa E, Ezike KN. 2019. Hydropic degeneration of uterine leiomyoma mimicking a huge ovarian cyst. International Journal of Case Reports and Images. vol 10: 1-6. doi: https://doi.org/10.5348/101002Z01IA2019CR.

Basaranoglu M, Basaranoglu G, Bugianesi E. 2015. Carbohydrate intake and nonalcoholic fatty liver disease: fructose as a weapon of mass destruction. Hepatobiliary Surgery and Nutrition. vol 4(2): 109116. doi: https://dx.doi.org/10.3978\%2Fj.issn.23043881.2014.11.05.

Bhupathiraju SN, Tucker KL. 2011. Coronary heart disease prevention: nutrients, foods, and dietary patterns. Clinica Chimica Acta. vol 412(17-18): 1493-1514.

doi: https://doi.org/10.1016/j.cca.2011.04.038.

Bryda EC. 2013. The mighty mouse: the impact of rodents on advances in biomedical research. Missouri Medicine. vol (3): 207-211.

Byrne CD, Targher G. 2015. NAFLD: a multisystem disease. Journal of Hepatology. vol 62(1): 47-64. doi: https://doi.org/10.1016/j.jhep.2014.12.012.

Freitas SH, Dória RGS, Bueno RS, Rocha WB, Filho JRE, Moraes JRE, Vidane AS, Ambrósio CE. 2017. Evaluation of potential changes in liver and lung tissue of rats in an ischemia-reperfusion injury model (modified pringle maneuver). PLoS One. vol 12(6): 1-13. doi: https://doi.org/10.1371/journal.pone.0178665. 
Gao X, Yu B, Yu J, Mao X, Huang Z, Luo Y, Luo J, Zheng P, He J, Chen D. 2020. Effects of dietary starch structure on growth performance, serum glucose-insulin response, and intestinal health in weaned piglets. Animals. vol 10(3): 1-15. doi: https://doi.org/10.3390/ani10030543.

Gargiulo S, Gramanzini M, Megna R, Greco A, Albanese S, Manfredi C, Brunetti A. 2014. Evaluation of growth patterns and body composition in $\mathrm{C} 57 \mathrm{Bl} / 6 \mathrm{~J}$ mice using dual energy X-ray absorptiometry. BioMed Research International. vol 2014: 1-12. doi: https://doi.org/10.1155/2014/253067.

Geng Y, Faber KN, de Meijer VE, Blokzijl H, Moshage H. 2021. How does hepatic lipid accumulation lead to lipotoxicity in non-alcoholic fatty liver disease? Hepatology International. vol 15: 21-35. doi: https://doi.org/10.1007/s12072-020-10121-2.

Gissen P, Arias IM. 2015. Structural and functional hepatocyte polarity and liver disease. Journal of Hepatology. vol 3(4): 1023-1037. doi: https://doi.org/10.1016/j.jhep.2015.06.015.

Hawkins P, Armstrong R, Boden T, Garside P, Knight K, Lilley E, Seed M, Wilkinson M, Williams RO. 2015. Applying refinement to the use of mice and rats in rheumatoid arthritis research. Inflammopharmacology. vol 23(4): 131-150. doi: https://doi.org/10.1007/s10787-015-0241-4.

Hickman DL, Johnson J, Vemulapalli TH, Crisler JR, Shepherd R. 2017. Commonly used animal models. In Principles of animal research for graduate and undergraduate students. New York: Elsevier Inc. pp 117-175. doi: https://dx.doi.org/10.1016\%2FB9780-12-802151-4.00007-4. Jarrar BM, Taib NT. 2012. Histological and histochemical alterations in the liver induced by lead chronic toxicity. Saudi Journal of Biological Sciences. vol 19(2): 203-210. doi: https://doi.org/10.1016/j.sjbs.2011.12.005.

Kementerian Kesehatan. 2021. Penyakit jantung koroner didominasi masyarakat Kota. Jakarta: Kementerian Kesehatan Republik Indonesia. https://www.kemkes.go.id/.

Lee KY, Yoo SH, Lee HG. 2012. The effect of chemically-modified resistant starch, RS type-4, on body weight and blood lipid profiles of high fat dietinduced obese mice. Starch-Stärke. vol 64(1): 7885. doi: https://doi.org/10.1002/star.201100057.

Li L, Mo F, Hui EP, Chan SL, Koh J, Tang NLS, Yu $\mathrm{SCH}$, Yeo W. 2019. The association of liver function and quality of life of patients with liver cancer. BMC Gastroenterology. vol 19: 1-12. doi: https://doi.org/10.1186/s12876-019-0984-2.

Lind L, Simon T, Johansson L, Kotti S, Hansen T, Machecourt J, Ninio E, Tedgui A, Danchin N, Ahlström H, Mallat Z. 2012. Circulating levels of secretory-and lipoprotein-associated phospholipase A2 activities: relation to atherosclerotic plaques and future all-cause mortality. European Heart Journal. vol 33(23): 2946-2954. doi: https://doi.org/10.1093/eurheartj/ehs132.

Maurice J, Manousou P. 2018. Non-alcoholic fatty liver disease. Clinical Medicine. vol 18(3): 245-250. doi: https://dx.doi.org/10.7861\%2Fclinmedicine.18-3245.

Murakami M, Yamamoto K, Miki Y, Murase R, Sato H, Taketomi Y. 2016. The roles of the secreted phospholipase A2 gene family in immunology. Advances in Immunology. vol 132: 91-134. doi: https://doi.org/10.1016/bs.ai.2016.05.001.

Murase R, Sato H, Yamamoto K, Ushida A, Nishito Y, Ikeda K, Kobayashi T, Yamamoto T, Taketomi Y, Murakami M. 2016. Group X secreted phospholipase A2 releases $\omega 3$ polyunsaturated fatty acids, suppresses colitis, and promotes sperm fertility. Journal of Biological Chemistry. vol 291(13): 6895-6911. doi: https://doi.org/10.1074/jbc.M116.715672.

Murwani S, Ali M, Muliartha K. 2013. Diet aterogenik pada tikus putih (Rattus novergicus strain Wistar) sebagai model hewan aterosklerosis. Jurnal Kedokteran Brawijaya. vol 22(1): 6-9. doi: http://dx.doi.org/10.21776/ub.jkb.2006.022.01.2.

Panqueva RDPL. 2013. Hepatopathology for gastroenterologists and hepatologists. Part two: Useful terminology in the interpretation of the histopathological findings. Revista Colombiana de Gastroenterologia. vol 28(3): 247-255.

Poston RN. 2019. Atherosclerosis: integration of its pathogenesis as a self-perpetuating propagating inflammation: a review. Cardiovascular Endocrinology \& Metabolism. vol 8(2): 51-61. doi: https://dx.doi.org/10.1097\%2FXCE.00000000000 00172.

Rahardjo T, Nurhayati S, Ramadhani D. 2013. Liver histophatological studies of mice (Mus musculus sp.) infected with gamma rays irradiated Plasmodium berghei strains Anka. HAYATI Journal of Biosciences. vol 20(3): 144-150. doi: https://doi.org/10.4308/hjb.20.3.144.

Ramos CAF, Sá RDCDS, Alves MF, Benedito RB, de Sousa DP, Diniz MDFFM, Araújo MST, de Almeida RN. 2015. Histopathological and biochemical assessment of d-limonene-induced liver injury in rats. Toxicology Reports. vol 2: 482488. https://doi.org/10.1016/j.toxrep.2015.01.001.

Rosenson RS, Hurt-Camejo E. 2012. Phospholipase A2 enzymes and the risk of atherosclerosis. European Heart Journal. vol 33(23): 2899-2909. doi: https://doi.org/10.1093/eurheartj/ehs148.

Ruan P, Yang C, Su J, Cao J, Ou C, Luo C, Tang Y, Wang Q, Yang F, Shi J, Lu X, Zhu L, Qin H, Sun W, Lao Y, Li Y. 2013. Histopathological changes in the liver of tree shrew (Tupaia belangeri chinensis) persistently infected with hepatitis B virus. Virology Journal. $\quad$ vol 10: 1-11. doi: https://doi.org/10.1186/1743-422X-10-333.

Santoso A, Heriansyah T, Rohman MS. 2020. Phospholipase A2 is an inflammatory predictor in cardiovascular diseases: is there any spacious room to prove the causation?. Current Cardiology 
Reviews. $\quad$ vol 16(1): 3-10. doi: https://doi.org/10.2174/1573403X1566619053111 1932.

Schulze RJ, Schott MB, Casey CA, Tuma PL, McNiven MA. 2019. The cell biology of the hepatocyte: A membrane trafficking machine. Journal of Cell Biology. vol 218(7): 2096-2112. doi: https://doi.org/10.1083/jcb.201903090.

Stanek M, Rotkiewicz T, Sobotka W, Bogusz J, OtrockaDomagała I, Rotkiewicz A. 2015. The effect of alkaloids present in blue lupine (Lupinus angustifolius) seeds on the growth rate, selected biochemical blood indicators and histopathological changes in the liver of rats. Acta Veterinaria Brno. vol 84(1): 55-62. doi: https://doi.org/10.2754/avb201585010055.

Szpirer C. 2020. Rat models of human diseases and related phenotypes: a systematic inventory of the causative genes. Journal of Biomedical Science. vol 27(1): 1-52. doi: https://doi.org/10.1186/s12929020-00673-8.
Wang L, Wang Y, Liang Y, Li J, Liu Y, Zhang J, Zhang A, Fu J, Jiang G. 2013. Specific accumulation of lipid droplets in hepatocyte nuclei of PFOAexposed BALB/c mice. Scientific Reports. vol 3(1): 1-5. doi: https://doi.org/10.1038/srep02174.

Zheng J, Ji C, Lu X, Tong W, Fan X, Gao Y. 2015. Integrated expression profiles of mRNA and microRNA in the liver of Fructus Meliae Toosendan water extract injured mice. Frontiers in Pharmacology. vol 6: 1-13. doi: https://doi.org/10.3389/fphar.2015.00236.

Zheng B, Wang T, Wang H, Chen L, Zhou Z. 2020. Studies on nutritional intervention of rice starcholeic acid complex (resistant starch type V) in rats fed by high-fat diet. Carbohydrate Polymers. vol 246: 1-35. doi: https://doi.org/10.1016/j.carbpol.2020.116637.

Zhou Z, Xu MJ, Gao B. 2016. Hepatocytes: a key cell type for innate immunity. Cellular \& Molecular Immunology. vol 13(3): 301-315. doi: https://doi.org/10.1038/cmi.2015.97. 